\title{
Perbedaan Lama Pelepasan Tali Pusat Berdasarkan Perawatan Tali Pusat Pada Bayi Baru Lahir
}

\author{
Hariyanto ${ }^{1)}$, Eva Febriana ${ }^{2)}$ \\ Akademi Kebidanan Harapan Mulya Ponorogo
}

\begin{abstract}
This study aimed at determining the difference in the length of umbilical cord release based on umbilical cord care. This research was conducted from February to April 2017. This type of research was an experimental research and the design used was cross sectional. The population in this study were 42 pregnant women estimated to give birth in February-April 2017. The sample of the research was 30 newborns taken with porposive sampling technique. Data collected by observation. Data were analyzed using $\mathrm{T}$ Test statistic test result.

The results showed that most, 19 respondents $(63,3 \%)$ had performed the umbilical cord care technique correctly. Almost half of respondents, 13 respondents $(43,3 \%)$ the umbilical cord was release fast. The significant level was $0,000<0,50$, so it was concluded that there was a difference in the length of umbilical cord removal based on umbilical cord care techniques. If the umbilical cord care is correct, it was removed or healed quickly.

Based on the results of the study is expected health workers, especially midwives are encouraged to continue using the correct care of the umbilical cord or sterile gauze because it only covers the umbilical cord with sterile gauze, the cord will dry faster and the cord will release quickly.
\end{abstract}

Key Words : the Umbilical Cord, Umbilical Cord Care Techniques, Newborn Baby.

\section{PENDAHULUAN}

Tali pusat atau umbilical cord adalah saluran kehidupan bagi janin selama didalam kandungan. Dikatakan saluran kehidupan karena saluran inilah yang selama 9 bulan 10 hari menyuplai zat-zat gizi dan oksigen ke janin. Tetapi, saat bayi lahir, saluran ini sudah tidak diperlukan lagi, sehingga harus dipotong dan diikat atau dijepit. Setelah dipotong, tindakan berikutnya adalah perawatan pada tali pusat yang telah dipotong. Sisa potongan tali pusat pada bayi inilah yang harus dirawat. Sebab, jika tidak dirawat maka dapat menyebabkan infeksi. (Putra, 2012:72)

Berdasarkan protap pemerintah
cara perawatan tali pusat tidak membungkus puntung tali pusat atau perut bayi atau mengoleskan cairan atau bahan apapun ke puntung tali pusat. Dapat mengoleskan alcohol atau betadine (terutama jika pemotongan tali pusat tidak terjamin DTT atau steril) masih diperkenankan tetapi tidak dikompreskan karena menyebabkan basah/lembab (JNPK-KR, 2008;99).

Perhatian terhadap upaya penurunan angka kematian neonatal (0-28 hari) menjadi penting karena kematian neonatal memberi kontribusi terhadap 59\% kematian bayi. Berdasarkan hasil Survei Demografi dan Kesehatan Indonesia (SDKI) tahun 2012, angka Kematian Neonatus (AKN) pada tahun 2012 sebesar 19 per 1.000 kelahiran hidup. Angka ini sama dengan AKN berdasarkan SDKI tahun 2007 dan hanya menurun 1 poin dibanding SDKI tahun 2002-2003 yaitu 20 per 1.000 kelahiran hidup. Hasil Survei Penduduk Antar Sensus (SUPAS) 2015 menunjukkan AKB sebesar 22,23 per 1.000 kelahiran hidup, yang artinya sudah mencapai target MDG 2015 sebesar 23 per 1.000 kelahiran hidup. Begitu pula dengan Angka Kematian Balita (AKABA) hasil SUPAS 2015 sebesar 26,29 per 
1.000 kelahiran hidup, juga sudah memenuhi target MDG 2015 sebesar 32 per 1.000 kelahiran hidup. (Dep.Kes.RI, 2015)

Keadaan Angka Kematian Bayi (AKB) dan Angka Kematian Neonatal (AKN) yang diperoleh dari laporan rutin relatif sangat kecil, sehingga data $\mathrm{AKB}$ yang dikeluarkan oleh Badan Pusat Statistik (Provinsi Jawa Timur) diharapkan mendekati kondisi di lapangan. Berdasarkan hasil Survei Sosial Ekonomi Nasional (Susenas) Jawa Timur Tahun 2011-2013, AKB Provinsi Jawa Timur tahun 2013 sebesar 27,23 per 1.000 kelahiran hidup. (Profil Kesehatan Jawa Timur, 2014)

Angka Kematian Bayi yang tercatat di Kabupaten Ponorogo pada tahun 2014 ini mengalami penurunan dibandingkan dengan angka kematian bayi yang tercatat pada pada Tahun 2013, dimana tercatat Angka Kematian Bayi Tahun 2014 adalah sebesar 14 (161 bayi) per 1000 kelahiran hidup sedangkan Tahun 2013 tercatat 14,45 (170 bayi) per 1000 kelahiran hidup.

Tetanus neonatorum disebabkan oleh basil Clostridium tetani, yang masuk ke tubuh melalui luka. Penyakit ini menginfeksi bayi baru lahir yang salah satunya disebabkan oleh pemotongan tali pusat dengan alat yang tidak steril. Kasus tetanus neonatorum banyak ditemukan di negara berkembang khususnya negara dengan cakupan persalinan oleh tenaga kesehatan yang rendah.

Gambaran kasus menurut faktor risiko penolong persalinan, 33 kasus (62\%) ditolong oleh penolong persalinan tradisional, misalnya dukun. Menurut cara perawatan tali pusat, hanya 6 kasus $(11 \%)$ yang dirawat menggunakan alkohol/iodium, sedangkan yang lain menggunakan cara tradisional, lain-lain dan tidak diketahui. Menurut alat yang digunakan untuk pemotongan tali pusat, 22 kasus (42\%) menggunakan gunting 12 kasus (59\%) menggunakan bambu dan sisanya menggunakan alat lain atau tidak diketahui. Menurut status imunisasi sebanyak 32 kasus (60\%) terjadi pada kelompok yang tidak diimunisasi. (Dep.kes.RI , 2015)

Dari hasil studi pendahuluan didapatkan pada bulan Agustus 2016 di Klinik Mutiara Delima terdapat 1 kasus bayi yang mengalami tali pusat bernanah dan berbau busuk saat kunjungan neonatal ini dikarenakan cara perawatan tali pusat yang kurang benar.

Berdasarkan studi pendahuluan yang dilakukan pada bulan November $2016 \mathrm{di}$ Klinik Mutiara Delima dari 12 persalinan didapatkan 5 responden $(41,67 \%)$ lama pelepasan tali pusatnya $8-10$ hari sedangkan 7 responden $(58,33 \%)$ lama pelepasan tali pusatnya 5-6 hari karena hal ini dipengaruhi cara perawatan tali pusat dan teknik perawatannya yang kurang tepat.

Menurut Putra (2012:209) tali pusat jika tidak dirawat dengan baik dapat menyebabkan terjadinya infeksi. Dan dampak perawatan tali pusat yang tidak benar dapat mengakibatkan terjadinya infeksi yang mengakibatkan penyakit tetanus neonatorum. (Dep.Kes.RI, 2015)

Dampak nyata dari cara perawatan tali pusat yang tidak benar yaitu terdapat 1 bayi yang lama pelepasan tali pusat menjadi lambat dan semakin memanjang hingga menyebabkan infeksi seperti tali pusat bernanah dan berbau busuk.

Faktor yang mempengaruhi lama lepasnya tali pusat : 1) Timbulnya infeksi ada tali pusat karena tindakan atau perawatan yang tidak memenuhi syarat kebersihan. 2) Cara perawatan tali pusat. Penelitian menunjukkan bahwa tali pusat yang dibersihkan dengan air dan sabun cenderung lebih cepat puput(lepas) dari pada tali pusat yang dibersihkan dengan alkohol. 3) Kelembapan tali pusat. 4) Kondisi sanitasi lingkungan sekitar neonatus dan Spora C. Tetani yang masuk melalui luka tali pusat karena tindakan atau perawatan yang tidak memenuhi syarat kebersihan. (Putra,2012:215-216)

Dari masalah yang sudah dipaparkan diatas maka solusinya yaitu perawatan tali pusat dengan menjaga agar tali pusat tetap kering dan bersih. Cuci tangan dengan sabun dan air bersih sebelum merawat tali pusat. Bersihkan lembut kulit 
disekitar tali pusat dengan kapas basah, kemudian bungkus dengan longgar/tidak terlalu rapat dengan kasa bersih/steril. (Prawirohardjo,2013:370)

Cara perawatan tali pusat akan mempengaruhi keadaan tali pusat, dan selain itu akan mencegah terjadinya infeksi. Berdasarkan latar belakang masalah tersebut maka penelitin tertarik untuk melakukan penelitian tentang perbedaan lama pelepasan tali pusat berdasarkan cara perawatan tali pusat.

\section{METODE PENELITIAN}

\section{Jenis Penelitian}

Jenis penelitian yang digunakan pada penelitian ini adalah eksperimen atau percobaan yaitu kegiatan percobaan (eksperimen) yang bertujuan untuk mengengrtahui suatu gejala atau pengaruh yang timbul, sebagai akibat dari adanya perlakuan tertentu (Notoatmodjo, 2005:156)

Tujuan utama penelitian eksperimen adalah untuk menyelidiki kemungkinan saling berhubungan sebab akibat dengan cara mengadakan intervensi atau mengadakan perlakuan kepada suatu kelompok atau lebih kelompok eksperimen, kemudian hasil (akibat) dari intervensi tersebut dibandingkan dengan kelompok yang tidak dikenakan perlakuan. (Notoatmodjo, 2005:156).

\section{Populasi , Sampel dan Teknik Sampling 1. Populasi}

Populasi pada penelitian ini adalah semua bayi baru lahir yang diteliti di Klinik Mutiara Delima di Desa Pangkal Kecamatan Sawoo Kabupaten Ponorogo pada bulan Februari sampai dengan April 2017.

\section{Sampel}

Sampel dalam penelitian ini adalah semua bayi baru lahir dalam bulan Februari-April2017 di Klinik Mutiara Delima. Kriteria sampel yang diapakai dalam penelitian ini ditentukan dengan menggunakan :
1) Kriteria Inklusi

Kriteria Inklusi adalah karakteristik umum subyek penelitian dari suatu populasi target yang terjangkau yang akan diteliti. (Nursalam, 2003:96)

Karakteristik dalam penelitian ini adalah :

a. Orang tua bayi baru lahir yang bersedia sebagai responden.

b. Bayi baru lahir di klinik Mutiara Delima desa Pangkal kecamatan Sawoo Kabupaten Ponorogo.

2) Kriteria Eksklusi

Kriteria Eksklusi adalah menghilangkan atau mengeluarkan subyek yang memenuhi kriteria inklusi dari studi karena berbagai sebab (Nursalam,2003:97). Kriteria eksklusi pada penelitian ini adalah:

a. Orang tua bayi yang tidak bersedia bayinya sebagai responden.

b. Orang tua bayi yang tidak kooperatif.

\section{Teknik Sampling}

Tehnik sampling yang digunakan adalah porposive sampling yaitu tehnik pengambilan sampel secara porposive didasarkan pada suatu pertimbangan tertentu yang dibuat oleh peneliti sendiri, berdasarkan ciri atau sifat-sifat populasi yang telah diketahui sebelumnya (Notoatmodjo, 2005:88). Pada penelitian ini telah ditentukan pada bulan FebruariApril 2017

\section{Instrumen Penelitian}

Penelitian ini menggunakan instrument observasi terstruktural untuk membantu proses pelepasan tali pusat berdasarkan cara perawatan tali pusat.

\section{Metode Pengumpulan Data}

Pengumpulan data pada penelitian ini melalui observasi terstruktur, pengukuran terstruktur, dimana peneliti secara cermat mendefinisikan apa yang akan diobservasi melalui suatu perencanaan yang matang. Peneliti tidak hanya mengobservasi fakta-fakta yang ada pada subyek, tetapi lebih didasarkan pada perencanaan penelitian yang sudah 
disusun sesuai pengelompokannya, pencatatan dan pemberian kode terhadap hal yang sudah diterapkan.

Dalam proses pengumpulan data pada cara perawatan tali pusat dan lama pelepasan menggunakan cara observasi.

Observasi pada tali pusat (semua responden sebelum dilakukan intervensi kondisi tali pusat telah dilakukan perawatan dengan baik dan benar serta dengan cara yang sama). Selanjutnya observasi akan dilakukan setiap hari yaitu pada saat setelah mandi pagi dan sore hari dengan dilakukan perawatan tali pusat. Observasi akan dilakukan sampai minimal 7 hari perawatan dan jika responden diperbolehkan pulang pelayanan rumah maka observasi dilanjutkan dirumah responden.

\section{Analisa Data}

\section{1) Univariat}

Analasis univariate bertujuan untuk menjelaskan atau mendeskripsikan karakteristik setiap variabel penelitian. Bentuk analisis univariate tergantung dari jenis datanya. Untuk data numerik digunakan nilai mean atau rata-rata, median dan standar deviasi. (Notoatmodjo, 2010:182)

Pengelolaan data karakteristik responden.

$$
\mathrm{P}=\frac{\sum F}{N} \times 100 \%
$$

Keterangan:

$\mathrm{P}=$ Prosenatase

$\mathrm{F}=$ Frekuensi Jawaban

$\mathrm{N}$ = Jawaban Responden

Hasil dari presentase dari pengolahan data diinterpretasikan dengan menggunakan skala kuantitatif sebagai berikut :

$$
\begin{array}{ll}
100 \% & : \text { Seluruhnya } \\
76 \%-99 \% & : \text { Hampir seluruhnya } \\
51 \%-75 \% & : \text { Sebagian besar } \\
50 \% & : \text { Setengah } \\
26 \%-49 \% & : \text { Hampir setengah } \\
1 \%-25 \% & : \text { Sebagian kecil } \\
0 \% & : \text { Tidak satupun }
\end{array}
$$

Analisis bevariate dilakukan terhadap dua variabel yang diduga berhubungan atau berkolerasi. Apabila telah dilakukan analisis univariate hasilnya akan diketahui karakteristik atau distribusi setiap variabel, dan dapat dilanjutkan analisis bevariate. (Notoatmodjo, 2010:183)

Data yang terkumpul dikelompokkan dan diberi kode sesuai dengan ketentuan yang ditetapkan, kemudian disajikan dalam bentuk tabel. Untuk membedakan lama lepasnya tali pusat antara cara perawatan benar dan salah, kemudian dilakukan uji statistik $T$ Test (tes T) menggunakan SPSS dengan tingkat kemaknaan $\alpha \leq 0,05$, yang berarti ada perbedaan lama pelepasan tali pusat berdasarkan cara perawatan tali pusat pada bayi baru lahir

\section{HASIL PENELITIAN}

1) Karakteristik Responden Berdasarkan Lama Pelepasan Tali Pusat

Tabel 1. Distribusi Frekuensi Responden Berdasarkan Lama Pelepasan Tali Pusat.

\begin{tabular}{llr}
\hline \multirow{2}{*}{$\mathrm{N}$} & Valid & 30 \\
\cline { 2 - 3 } & Missing & 0 \\
\hline Mean & 5.77 \\
\hline Median & 5.00 \\
\hline Mode & 4 \\
\hline Minimum & 2 \\
\hline Maximum & 10 \\
\hline Sum & 173 \\
\hline
\end{tabular}

Berdasarkan tabel diatas dapat diintepretasikan bahwa nilai rata-rata lama pelepasan tali pusat adalah 5,77 hari, nilai tengahnya adalah 5 hari, nilai yang sering muncul adalah 4 hari, nilai minimumnya adalah 2 hari, nilai maksimumnya adalah 10 hari, dan jumlahnya adalah 173 hari.

2) Bivariat 


\begin{tabular}{|c|c|c|}
\hline Nilai & Frekuensi & Prosentase (\%) \\
\hline 45 & 1 & 2.4 \\
\hline 50 & 4 & 9.5 \\
\hline 55 & 5 & 11.9 \\
\hline 60 & 5 & 11.9 \\
\hline 65 & 3 & 7.1 \\
\hline 70 & 9 & 21.4 \\
\hline 75 & 8 & 19.0 \\
\hline 80 & 2 & 4.8 \\
\hline 85 & 3 & 7.1 \\
\hline 90 & 2 & 4.8 \\
\hline Total & 42 & 100 \\
\hline & & \\
\hline
\end{tabular}

Berdasarkan Tabel 1 diatas diketahui bahwa responden dengan nilai 45 sebanyak 1 responden $(2,4 \%)$, responden dengan nilai 50 sebanyak 4 responden $(9,5 \%)$, responden dengan nilai 55 sebanyak 5 responden $(11,9 \%)$, responden dengan nilai 60 sebanyak 5 responden(11,9\%), responden dengan nilai 65 sebanyak 3 responden $(7,1 \%)$, responden dengan nilai 70 sebanyak 9 responden $(21,4)$, responden dengan nilai 75 sebanyak 8 responden(19\%)responden dengan nilai 80 sebanyak 2 responden $(4,8 \%)$, responden dengan nilai 85 sebanyak 3 responden $(7,1 \%)$, dan responden dengan nilai 90 sebanyak 2 responden $(4,8 \%)$.

\section{2) Distribusi Frekuensi Responden Berdasarkan Kategori Lama Pelepasan Tali Pusat}

Tabel 2. Distribusi Nilai Pelepasan Tali Pusat

\begin{tabular}{|c|c|c|c|c|c|}
\hline & & Frequency & Percent & $\begin{array}{l}\text { Valid } \\
\text { Percent }\end{array}$ & $\begin{array}{c}\text { Cumulati } \\
\text { ve } \\
\text { Percent }\end{array}$ \\
\hline \multirow[t]{4}{*}{ Valid } & cepat & 13 & 43.3 & 43.3 & 43.3 \\
\hline & normal & 6 & 20.0 & 20.0 & 63.3 \\
\hline & lambat & 11 & 36.7 & 36.7 & 100.0 \\
\hline & Total & 30 & 100.0 & 100.0 & \\
\hline
\end{tabular}

Berdasarkan tabel 2 dapat esponden dengan pelepasan tali pusatnya cepat yaitu 13 responden $(43,3 \%)$, responden yang pelepasan tali pusatnya normal sebanyak 6 responden (20\%), dan responden yang lama pelepasan tali pusatnya lambat sebanyak 11 responden $(36,7 \%)$

3) Analisis Perbedaan Lama Pelepasan Tali Pusat Berdasarkan Cara Perawatan Tali Pusat

Berikut ini disajikan uji statistik Independent T-Test, Perbedaan Lama Pelepasan Tali Pusat Berdasarkan Cara Perawatan Tali Pusat pada Bayi Baru lahir. 
Tabel 3. Uji statistik Perbedaan Lama Pelepasan Tali Pusat Berdasarkan Cara Perawatan Tali Pusat

\begin{tabular}{|c|c|c|c|c|c|c|c|c|c|c|}
\hline & & \multicolumn{2}{|c|}{$\begin{array}{l}\text { Levene's Test } \\
\text { for Equality of } \\
\text { Variances }\end{array}$} & \multicolumn{7}{|c|}{ t-test for Equality of Means } \\
\hline & & \multirow[b]{2}{*}{$\mathrm{F}$} & \multirow[b]{2}{*}{ Sig. } & \multirow[b]{2}{*}{$\mathrm{t}$} & \multirow[b]{2}{*}{ df } & \multirow{2}{*}{$\begin{array}{l}\text { Sig. (2- } \\
\text { tailed) }\end{array}$} & \multirow{2}{*}{$\begin{array}{c}\text { Mean } \\
\text { Difference }\end{array}$} & \multirow{2}{*}{$\begin{array}{l}\text { Std. Error } \\
\text { Difference }\end{array}$} & \multicolumn{2}{|c|}{$\begin{array}{c}95 \% \text { Confidence Interval of the } \\
\text { Difference }\end{array}$} \\
\hline & & & & & & & & & Lower & Upper \\
\hline $\begin{array}{l}\text { Lama_pel } \\
\text { epasan }\end{array}$ & $\begin{array}{l}\text { Equal variances } \\
\text { assumed }\end{array}$ & .111 & .741 & -11.889 & 28 & .000 & -4.531 & .381 & -5.312 & -3.750 \\
\hline & $\begin{array}{l}\text { Equal variances not } \\
\text { assumed }\end{array}$ & & & & 26.195 & .000 & -4.531 & .351 & -5.252 & -3.810 \\
\hline
\end{tabular}

Berdasarkan tabel 3 dengan hasil perhitungan menggunakan Independent T-Test dengan taraf signifikan 0,05 yaitu $\mathrm{p}=0,000$ sehingga $\mathrm{p}<0,05$ maka $\mathrm{H}_{1}$ diterima dan Ho ditolak, sehingga ada perbedaan lama pelepasan tali pusat berdasarkan cara perawatan tali pusat pada bayi baru lahir di Klinik Mutiara Delima Desa Pangkal Kecamatan Sawoo Kabupaten Ponorogo

\section{PEMBAHASAN}

\section{Teknik Perawatan Tali Pusat}

Berdasarkan hasil penelitian didapatkan dari 30 responden sebanyak 19 responden (63.3\%) menggunakan cara perawatan tali pusat yang benar, dan 11 responden $(36,7 \%)$ menggunakan cara perawatan tali pusat yang salah. Cara perawatan tali pusat dengan kassa steril adalah dengan membungkus tali pusat dengan kasa dan mengkondisikan tali pusat tetap kering. (Putra, 2012: 213-214)

Perawatan tali pusat yang benar dan lepasnya tali pusat dalam minggu pertama secara bermakna mengurangi insiden infeksi pada neonatus. Jelly wharton yang membentuk jaringan nekrotik dapat berkolonisasi dengan orgenisme patogen, kemudian menyebar dan menyebabkan infeksi kulit dan infeksi sistemik pada bayi. yang terpenting dalam perawatan tali pusat adalah menjaga agar tali pusat tetap kering dan bersih. Cuci tangan dengan sabun dan air bersih sebelum merawat tali pusat. Bersihkan lembut kulit disekitar tali pusat dengan kapas basah, kemudian bungkus dengan longgar/tidak terlalu rapat dengan kasa bersih/steril. Popok atau celana bayi diikat dibawah tali pusat, tidak menutupi tali pusat untuk menghindari kontak dengan feses dan urin. (Prawirohardjo, 2013: 370-371).

Masih adanya perawatan tali pusat yang salah dimungkinkan disebabkan karena jenjang pendidikan ibu dan tingkat pengetahuan ibu yang masih kurang tentang cara perawatan tali pusat yang benar. Berdasarkan data yang diperoleh dari responden sebanyak 23 responden (76,7\%) masih berpendidikan dasar, yaitu SD sebanyak 8 responden $(26,7 \%)$ dan SMP sebanyak 15 responden (50\%)

Berdasarkan data diatas dapat diambil opini bahwa perlu adanya kepedulian dari petugas kesehatan setempat untuk memberikan penyuluhan kepada ibu tentang cara perawatan tali pusat yang benar dan kita berikan umpan balik pada ibu dengan cara mempratikkannya kembali sehingga ibu paham betul cara perawatan tali pusat yang benar.

\section{Lama Pelepasan Tali Pusat}

Hasil penelitian dari 30 responden menunjukkan bahwa lama pelepasan tali pusat yang cepat adalah 2 hari, sedangkan lama pelepasan tali pusat yang paling lambat adalah 10 hari, dan rata-rata lama pelepasan tali pusatnya adalah 6 hari. Berdasarkan kategori lama pelepasan tali pusat didapatkan responden dengan pelepasan tali pusatnya cepat sebanyak 13 responden $(43,3 \%)$, responden yang pelepasan tali pusatnya normal sebanyak 6 responden $(20 \%)$, dan responden yang lama pelepasan tali pusatnya lambat sebanyak 11 responden $(36,7 \%)$. 
Tujuan dari perawatan tali pusat ini adalah untuk mencegah terjadinya infeksi dan mempercepat proses pengeringan dan pelepasan tali pusat. Lama penyembuhan tali pusat dikatakan cepat jika kurang dari 5 hari. Penyembuhan normal jika antara 5-7 hari, dan lambat jika lebih dari 7 hari. Faktor yang mempengaruhi lama lepasnya tali pusat: 1) Timbulnya infeksi ada tali pusat karena tindakan atau perawatan yang tidak memenuhi syarat kebersihan. 2) Cara perawatan tali pusat. Penelitian menunjukkan bahwa tali pusat yang dibersihkan dengan air dan sabun cenderung lebih cepat puput (lepas) dari pada tali pusat yang dibersihkan dengan alkohol. 3) Kelembapan tali pusat. 4) Kondisi sanitasi lingkungan sekitar neonatus dan Spora C. Tetani yang masuk melalui luka tali pusat karena tindakan atau perawatan yang tidak memenuhi syarat kebersihan. (Putra, 2012: 215-216)

Bersadarkan data diatas dapat diambil opini bahwa hampir setengah dari responden lama pelepasan tali pusatnya cepat hal ini dikarenakan cara perawatan tali pusatnya menggunakan cara perawatan yang benar, dan hampir setengahnya lama pelepasan tali pusatnya masih lambat. Dari hal tersebut kita dapat melihat bila ibu menggunakan perawatan tali pusat yang benar untuk anaknya maka semakin cepat waktu pelepasan tali pusatnya, dan sebaliknya bila ibu menggunakan perawatan yang salah maka waktu pelepasan tali pusat akan semakin lambat. Oleh karena itu maka petugas kesehatan setempat terutama bidan perlu melakukan penyuluhan dan bimbingan cara perawatan tali pusat yang benar.

\section{Perbedaan Lama Pelepasan Tali Pusat Berdasarkan Teknik Perawatan Tali Pusat}

Berdasarkan hasil uji statistik T Test menggunakan program SPSS for windows 16.0 dapat diketahui bahwa $\alpha$ sebesar 0,000 yang berarti $0,000<0,05$, sehingga dapat disimpulkan bahwa ada perbedaan lama pelepasan tali pusat berdasarkan cara perawatan tali pusat pada bayi baru lahir.
Hasil penelitian tersebut diketahui adanya perbedan antara tali pusat yang dirawat dengan perawatan tali pusat yang benar lebih cepat lepasnya dari pada dengan tali pusat yang dirawat dengan perawatan tali pusat yang salah dan perbedaan hasil uji $T$ Test ada perbedaan yang signifikan. Hal ini dikarenakan perawatan tali pusat yang benar dibiarkan terbuka dan hanya ditutup dengan kassa steril memudahkan terpapar dengan udara luar sehingga terhindar dari suasana lembab dan memudahkan proses pengeringan dan pelepasannya. Cara perawatan tali pusat dengan kassa steril adalah dengan membungkus tali pusat dengan kasa dan mengkondisikan tali pusat tetap kering. (Putra, 2012: 213-214)

Hasil penelitian ini seiring dengan hasil penelitian Eprilia (2013), dengan judul lama lepas tali pusat berdasarkan metode perawatan tali pusat pada bayi baru lahir, dengan hasil data ada perbedaan yang signifikan ditentukan dengan nilai $\mathrm{p}<0,05$. Ini menunjukkan ada perbedaan lama lepas tali pusat berdasarkan metode perawatan tali pusat pada bayi baru lahir.

Perawatan tali pusat sebaiknya dilakukan dua kali sehari atau setiap bayi dimandikan. Tali pusat yang basah atau lembab akan menyebabkan lambatnya pelepasan tali pusat. Selain itu tali pusat yang lembab juga menimbulkan resiko infeksi yang besar, dengan tali pusat lembab kuman atau bakteri akan mudah masuk. Waktu yang digunakan dalam perawatan tali pusat yang benar menggunakan kassa kering steril cukup cepat karena kerja dari kasa menyerap dan menyebabkan tali pusat mudah menjadi kering dan lekas terlepas dari pusat bayi.

\section{KESIMPULAN}

1. Sebagian besar responden $19(63,3 \%)$ responden dirawat dengan cara perawatan tali pusat yang benar.

2. Hampir setengahnya $13 \quad(43,3 \%)$ responden tali pusatnya lepas dengan cepat.

3. Ada perbedaan lama pelepasan tali pusat berdasarkan cara perawatan tali 
pusat di Klinik Mutiara Delima Desa Pangkal Sawoo Ponorogo.

\section{DAFTAR PUSTAKA}

DepKes RI. 2015. Profil Kesehatan Indonesia.

DinKes Jatim. 2014. Profil Kesehatan Provinsi Jawa Timur.

DinKes Ponorogo. 2014. Profil Kesehatan Kabupaten Ponorogo.

Eprilia, dkk. 2013. Lama Lepas Tali Pusat Berdasarkan Metode Perawatan Tali Pusat Pada Bayi Baru lahir di BPM Ellna dan RB Budi Indah Palembang. (Online, Pdf).

Evelin \& Djamaludin, N. 2010. Panduan Pintar Merawat Bayi dan Balita. Jakarta : Wahyu Media.

JNPK-KR. 2008. Pelatihan Asuhan Persalinan Normal Bahan Tambahan Inisiasi Menyusu Dini.

Lumsden \& Holmes. 2012. Asuhan Kebidanan Pada Bayi Yang Baru Lahir. Yogyakarta: Pustaka Pelajar.

Maryunani, A. 2014. Asuhan Neonatus, Bayi, Balita, dan Anak PraSekolah. Jakarta : In Media.

Notoatmodjo, Soekidjo. 2005. Metodologi Penelitian Kesehatan. Jakarta : PT Rineka Cipta.

2012. Metodologi Penelitian

Kesehatan. Jakarta : PT Rineka Cipta.

Nursalam. 2003. Konsep \& Penerapan Metodologi Penelitian Ilmu Keperawatan: Pedoman Skripsi, Tesis dan Instrumen Penelitian. Jakarta : Salemba Medika.

Prawirohardjo, Sarwono. 2006. Buku Acuan Nasional Pelayanan Kesehatan Maternal dan Neonatal. Jakarta : Yayasan Bina Pustaka Sarwono Prawirohardjo.

Sarwono Prawirohardjo. 2013. Ilmu Kebidanan. Jakarta : P.T. Bina Pustaka.

Putra, S. 2012. Asuhan Neonatus Bayi dan Balita Untuk Keperawatan dan Kebidanan. Jogjakarta : D-Medika. 